\title{
Evaluation of neutrophil elastase/ alpha-1-antitrypsin ratio in different stages of chronic obstructive pulmonary disease (COPD) patients
}

\author{
Pawar R.S ${ }^{1}$, Abhang S.A ${ }^{2}$ \\ ${ }^{1}$ Miss Rupali S. Pawar, Research Scholar, ${ }^{2}$ Dr. Subodhini A. Abhang, Professor, both authors are affiliated with \\ Department of Clinical Biochemistry, B. J. Govt. Medical College and Sassoon General Hospital, Pune, \\ Maharashtra, India
}

Address for Correspondence: Miss Rupali S. Pawar. Email: rupali.pawar55@gmail.com

\begin{abstract}
Introduction: Little is known about protease, anti-protease markers in chronic obstructive pulmonary disease (COPD) patients. Objectives: The objective of present study was to identify and try to correlate serum markers of protease and anti-protease with pulmonary functions in different stages of patients with COPD and to determine the ratio of neutrophil elastase/alpha-1-antitrypsin in different stages of COPD patients. Methods: This prospective observational study was carried out in patients with stable COPD. Activities of serum alpha-1antitrypsin and neutrophil elastase were measured in 220 stable COPD patients and in 60 healthy controls by ELISA method. 220 COPD patients were divided into 4 stages according to severity: stage I, II, III and IV.

Results: An increase in serum neutrophil elastase and neutrophil elastase/alpha-1-antitrypsin ratio was observed in COPD patients with the advancement of the stage. In contrast to that, decreased activity of alpha-1-antitrypsin in serum was observed in different stages of COPD and is correlated positively with lung function parameters. Conclusion: From these findings we conclude that as the severity increases there is decrease in alpha-1antitrypsin resulting in concomitant increase in neutrophil elastase activity causing imbalance between proteaseantiprotease in COPD patients and this imbalance is associated with impairment of lung function. The neutrophil elastase/ $\alpha$-1-antitrypsin ratio can tell us the severity of the chronic obstructive pulmonary disease it may be in terms of increased fibrosis of the lung. Though the magnitude of neutrophil elatase/alpha-1antitrypsin ratio is minute, still it can be a good marker of pulmonary function in term of severity of the COPD.
\end{abstract}

Keywords: Alpha-1-antitrypsin, Neutrophil elastase, Chronic obstructive pulmonary disease

\section{Introduction}

Chronic Obstructive Pulmonary Disease (COPD) is a global health problem affecting nearly 300 million people worldwide and killing 3 million individuals each year. COPD is the major cause of mortality will rise 7 to 8 million by year 2030 [1].

COPD is a disease of progressive, irreversible airflow limitation that is characterized by inflammatory response of lung to the noxious particles and gases [2]. In India, tobacco smoking is the major risk factor for the development of

Manuscript received: $20^{\text {th }}$ June 2017

Reviewed: $30^{\text {th }}$ June2017

Author Corrected: $8^{\text {th }}$ July 2017

Accepted for Publication: $15^{\text {th }}$ July 2017 chronic obstructive lung disease [3]. However, currently there are no drugs available that can reduce progression of airflow obstruction in COPD patients $[4,5]$.

Protease-anti-protease balance is required for normal function of the lung. Under normal conditions anti-proteases are present abundantly in lung tissue which balance the effect of neutrophil elastase and it provide anti-protease screen in the lungs. A shift of balance towards increased protease expression and activity can lead to increased inflammation and development of 
chronic lung disease such as emphysema and chronic obstructive pulmonary disease [6].

Alpha-1-antitrypsin is also known as $\alpha 1$-protease inhibitor. Alpha-1-antitrypsin is the most abundant serine protease inhibitor in human lungs and it also present in plasma. Alpha-1-antitrypsin is a single polypeptide chain consists of 394 amino acids. Its molecular weight is 52000 Dalton [7,8]. Alpha-1antitrypsin is mainly produced in liver.

It is also synthesized in little amount in blood monocytes, macrophages, neutrophils and in pulmonary alveolar cells [9-11]. Alpha-1antitrypsin has main function is to inhibit the activity of neutrophil elastase and to protect the lung against the deleterious effects of neutrophil elastase [12].

In healthy lungs, proteases are involved in cellular regeneration, cellular repair and tissue homeostasis [13]. In our study we studied role of protease (neutrophil elatase) in COPD patients. Neutrophil elastase is degrading enzyme released from neutrophils. Its main function is to destroy extracellular matrix, modifies airway epithelial cells and to disturbed respiratory host defense mechanisms. Neutrophil elastase acts as modulator of inflammation $[14,15]$.

In previous study it has been reported that increased expression of neutrophil elastase leads to the development of emphysema [16,17]. Therefore, present study was aimed to see whether there is any correlation between levels of alpha-1-antitrypsin, neutrophil elastase with the lung function parameters in COPD patients. In addition to this, to see whether the neutrophil elastase /alpha-1antitrypsin ratio can be use a marker for assessing the degree of severity of disease.

\section{Materials and Methods}

2.1.1. Selection of healthy controls: Control group consisted of 60 age and sex-matched healthy volunteers with no history of COPD, confirmed by spirometric tests performed during medical examination prior to the study.

2.1.2. Selection of study groups: COPD diagnosis for all patients included in the study was made by the evaluation of pulmonary function tests by using spirometer. Study subjects were aged in between of
40-75 yrs. Patients with all stages of COPD were included if they had a post-bronchodilator forced expiratory volume in one seconds $\left(\mathrm{FEV}_{1}\right)$ /force vital capacity $(\mathrm{FVC})<70 \%$ after $400 \mu \mathrm{g}$ of inhaled salbutamol.

220 stable COPD patients were classified into four stages according to GOLD (Global Initiative for Obstructive Lung Disease) guidelines based on the post- bronchodilator values of $\mathrm{FEV}_{1} \%$ predicted with $\mathrm{FEV}_{1} / \mathrm{FVC} \%$ ratio $<70 \%$ after performing lung function test, these are as follows:

a) Stage I COPD: ( $n=51$, post-bronchodilator $\mathrm{FEV}_{1}$ $\geq 80 \%, \mathrm{FEV}_{1} / \mathrm{FVC} \%$ ratio $<70 \%$ ),

b)Stage II COPD: ( $\mathrm{n}=57$, post-bronchodilator $\mathrm{FEV}_{1}$ $\geq 50 \%$ and $<80 \%, \mathrm{FEV}_{1} / \mathrm{FVC} \%$ ratio $<70 \%$ ),

c) Stage III COPD: ( $\mathrm{n}=59$, post-bronchodilator $\mathrm{FEV}_{1} \geq 30 \%$ and $<50 \%, \mathrm{FEV}_{1} / \mathrm{FVC} \%$ ratio $<$ $70 \%)$,

d) Stage IV COPD: ( $\mathrm{n}=53$, post-bronchodilator $\mathrm{FEV}_{1}<30 \%, \mathrm{FEV}_{1} / \mathrm{FVC} \%$ ratio $<70 \%$ ).

\subsubsection{Inclusion Criteria}

1. The patient was willing to participate in the study (i.e. patients written consent)

2. Smoking history of $>20$ packs per year

3. Post bronchodilator increase in $\mathrm{FEV}_{1}<12 \%$

4. Patients were clinically stable (no exacerbation for 2 months) at the time of the evaluation.

5. Patients age $>40$ yrs were included in the study.

2.1.4. Exclusion Criteria for Controls and COPD patients groups: Patients who were suffering from or who were known to have tuberculosis, pneumonia, asthma, bronchiectasis, lung cancer, interstitial lung disease, respiratory failure, cardiac failure, diabetes mellitus, hepatic disease, renal disease and who had any recent surgical intervention and who were unable to performed lung function test were excluded from our COPD patients group.

Healthy individual with any past history of lung/respiratory disease or with abnormal lung function test were excluded from Control group. 
Collection of Blood Samples: Under aseptic condition and with prior written consent of the subject, $4 \mathrm{ml}$ of blood was collected in plain bulb, allowed to clot for $1 \mathrm{hr}$. Serum was separated by centrifugation at $3000 \mathrm{rpm}$ for $10 \mathrm{~min}$. at room temperature, separated serum was aliquot and stored at $-80^{\circ} \mathrm{C}$ until the analysis and was used for the estimation of serum alpha-1-antitrypsin, neutrophil elastase and neutrophil elastase/alpha-1antitrypsin ratio.

Pulmonary Function Test: Pulmonary Function test was done by using Spirometer.

Measurement of Forced Vital Capacity and Forced Expiratory Volume was done in First seconds.

The $\mathrm{FEV}_{1} / \mathrm{FVC}$ is calculated using the maximum $\mathrm{FEV}_{1}$ and FVC from the technically acceptable, though not from the same curves. Values of $\mathrm{FEV}_{1} \%$ predicted, $\mathrm{FVC}$ and $\mathrm{FEV}_{1} / \mathrm{FVC} \%$ ratio have been noted. The Data was obtained from the printer, attached to spirometer.

Estimation of Serum Neutrophil Elastase: Serum Neutrophil elastase was determined by ELISA method (Welldone Biotech., EIAab Science Co. Ltd, USA).

This method is based on the principle that micro titer plate provided in the kit has been pre-coated with antibody specific to neutrophil elastase.

Standards or samples are then added to the appropriate micro titer plate wells with biotinconjugated polyclonal antibody preparation specific for Neutrophil elastase (NE) and Avidin conjugated to Horseradish Peroxidase (HRP) is added to each well and incubated.

Then a TMB substrate solution is added to each well. Only those wells that contain neutrophil elastase biotin conjugated antibody and enzymeconjugated avidin will exhibit a change in color.

The enzyme-substrate reaction is terminated by the addition of sulphuric acid solution and the color change is measured spectrophotometrically at wavelength of $450 \mathrm{~nm}$. The concentration of Neutrophil elastase in the samples is then determined by compared the O.D. of the samples to the standard curve. It was expressed as $\mathrm{pg} / \mathrm{ml}[18]$.
Estimation of alpha-1-antitrypsin: Enzyme linked immunosorbant assay (ELISA) test is used to determine human alpha-1-antitrypsin according to the "sandwich"-principle (Welldone Biotech., EIAab Science Co. Ltd, USA).

Alpha-1-antitrypsin in sample, standard and controls binds to antibodies, which are coated to the microtiterplate. After a washing step a peroxidase labelled detection antibody is added.

A second washing step is followed by the addition of the substrate which is converted to a colored product by peroxidase. The reaction is terminated by the addition of an acidic stop solution.

The optical densities are read at $450 \mathrm{~nm}$ (against the reference wavelength $620 \mathrm{~nm}$ ) in a microtiterplate reader.

The alpha-1-antitrypsin concentration can be calculated from the standard curve. The activity of alpha-1-antitrypsin is expressed in $\mathrm{mg} / \mathrm{dl}$ [19].

Statistical Analysis: Statistical analysis was carried out by using Statistical Package for Social Sciences (SPSS 17 version) software. The data was expressed as Mean \pm SD.

The statistical significance of the results among healthy controls and different stages of COPD patients was analyzed by using unpaired ' $\mathrm{t}$ ' test.

One way analysis of variance (ANOVA) was used for to compare mean values in all groups followed by multiple comparisons between the groups was done by Tukey post hoc tests. $\mathrm{P}$ value of $<0.05$ was considered as statistical significant.

The strength of association between measured parameters among different stages of COPD patients with pulmonary function test parameters was analyzed by correlation coefficient analysis.

In addition to this, a receiver operating characteristic (ROC) curve was used to determine the optimal cut-off point for studied biochemical parameters as a classifier of COPD according to the highest sensitivity and specificity.

ROC curve was determined by using MedCalc Software. 
ISSN- 2321-127X

Original Research Article

\section{Results}

Table No.-1: Demographic Characteristics of patients with COPD and healthy controls involved in the study (the data expressed as mean $\pm \mathrm{SD}$ )

\begin{tabular}{|c|c|c|c|c|c|}
\hline Variables & $\begin{array}{c}\text { Healthy } \\
\text { Controls } \\
(n=60)\end{array}$ & $\begin{array}{l}\text { COPD } \\
\text { Stage I } \\
(n=51)\end{array}$ & $\begin{array}{c}\text { COPD } \\
\text { Stage II } \\
(n=57)\end{array}$ & $\begin{array}{c}\text { COPD } \\
\text { Stage III } \\
(n=59)\end{array}$ & $\begin{array}{c}\text { COPD } \\
\text { Stage IV } \\
(n=53)\end{array}$ \\
\hline Age (years) & $54.93 \pm 9.013$ & $59.47 \pm 9.30$ & $62.91 \pm 8.44$ & $61.20 \pm 7.45$ & $61.73 \pm 8.04$ \\
\hline $\begin{array}{c}\text { Smoking history } \\
\text { Pack years }\end{array}$ & ----- & $52.1 \pm 4.74$ & $52.36 \pm 7.25$ & $53.56 \pm 8.26$ & $55.16 \pm 8.97$ \\
\hline $\begin{array}{l}\text { BMI (weight in } \\
\mathrm{kg} / \text { height in } \mathrm{m}^{2} \text { ) }\end{array}$ & $24.66 \pm 2.622$ & $24.08 \pm 3.36^{a}$ & $21.07 \pm 3.278^{c}$ & $19.97 \pm 3.63^{e}$ & $18.25 \pm 2.90^{h}$ \\
\hline $\mathrm{FEV}_{1} \%$ Predicted & $109.71 \pm 14.90$ & $86.17 \pm 7.01^{b}$ & $64.26 \pm 7.57^{d}$ & $41.16 \pm 5.99^{f}$ & $21.88 \pm 4.18^{i}$ \\
\hline FVC $\%$ predicted & $110.16 \pm 9.77$ & $97.72 \pm 12.42^{b}$ & $66.91 \pm 8.00^{d}$ & $62.66 \pm 7.45^{f}$ & $48.28 \pm 8.25^{i}$ \\
\hline $\begin{array}{c}\mathrm{FEV}_{1} / \mathrm{FVC} \% \\
\text { Ratio }\end{array}$ & $103.58 \pm 10.40$ & $65.05 \pm 4.6^{b}$ & $62.40 \pm 4.23^{c}$ & $60.05 \pm 4.93^{g}$ & $57.51 \pm 7.25^{j}$ \\
\hline
\end{tabular}

Values were expressed as Mean \pm SD

${ }^{a} \mathrm{P}=0.155$ statistically not significant as compare to healthy controls

${ }^{b} \mathrm{P}=0.0001$ statistically extremely significant as compare to healthy controls

${ }^{c} \mathrm{P}=0.001$ statistically extremely significant as compare to stage I COPD

${ }^{d} \mathrm{P}=0.0001$ statistically extremely significant as compare to stage I COPD

${ }^{e} \mathrm{P}=0.044$ statistically significant as compare to stage II COPD

${ }^{f} \mathrm{P}=0.0001$ statistically extremely significant as compare to stage II COPD

${ }^{g} \mathrm{P}=0.003$ statistically significant as compare to stage II COPD

${ }^{h} \mathrm{P}=0.003$ statistically significant as compare to stage III COPD

${ }^{i} \mathrm{P}=0.0001$ statistically extremely significant as compare to stage III COPD

${ }^{j} \mathrm{P}=0.01$ statistically significant as compare to stage III COPD

Table No.-2: Descriptive Statistic (mean \pm SD) of Alpha-1-antitrypsin (mg/dl), Neutrophil elastase (pg/ml) and ratio of Neutrophil elastase / Alpha-1-antitrypsin ratio $(\mathrm{mg} / \mathrm{dl})$ in patients with different COPD stages and healthy controls.

\begin{tabular}{|c|c|c|c|c|c|}
\hline Parameters & $\begin{array}{c}\text { HealthyControls } \\
\text { Mean } \pm \text { SD } \\
(n=60)\end{array}$ & $\begin{array}{c}\text { Stage I COPD } \\
\text { Mean } \pm \text { SD } \\
(n=51)\end{array}$ & $\begin{array}{c}\text { Stage II COPD } \\
\text { Mean } \pm \text { SD } \\
(n=57)\end{array}$ & $\begin{array}{c}\text { Stage III COPD } \\
\text { Mean } \pm \text { SD } \\
(n=59)\end{array}$ & $\begin{array}{c}\text { Stage IV COPD } \\
\text { Mean } \pm \text { SD } \\
(n=53)\end{array}$ \\
\hline $\begin{array}{c}\text { Alpha-1- } \\
\text { antitrypsin (mg/dl }\end{array}$ & $161.6 \pm 33.59$ & $119.0 \pm 24.9^{a}$ & $105.4 \pm 15.5^{a b}$ & $73.5 \pm 19.1^{a d}$ & $54.7 \pm 9.8^{a d}$ \\
\hline $\begin{array}{c}\text { Neutrophil } \\
\text { Elastase }(\mathrm{pg} / \mathrm{ml})\end{array}$ & $287.0 \pm 71.23$ & $348.8 \pm 92.8^{a}$ & $392.7 \pm 78.5^{a c}$ & $435.5 \pm 75.8^{a d}$ & $478.1 \pm 64.7^{a d}$ \\
\hline $\begin{array}{c}\text { Neutrophil } \\
\text { elastase/ Alpha- } \\
\text { 1-antitrypsin } \\
\text { ratio }(\mathrm{mg} / \mathrm{dl})\end{array}$ & $\begin{array}{c}(1.86 \pm 0.64) \\
\times 10^{-7}\end{array}$ & $\begin{array}{l}(3.11 \pm 1.2) \\
\mathrm{X} 10^{-7} a\end{array}$ & $\begin{array}{c}(4.30 \pm 1.04) \\
\times 10^{-7} a b\end{array}$ & $\begin{array}{c}(5.91 \pm 1.59) \\
\times 10^{-7} \text { ad }\end{array}$ & $\begin{array}{c}(7.14 \pm 2.70) \\
X 10^{-7} \text { ad }\end{array}$ \\
\hline
\end{tabular}

${ }^{a} \mathrm{P}=0.001$ statistically significant when compared to healthy controls

${ }^{b} \mathrm{P}=0.016$ statistically significant when compared to stage I

${ }^{c} \mathrm{P}=0.027$ statistically significant when compared to stage I

${ }^{d} \mathrm{P}=0.0001$ statistically significant when compared to stage I 
Table No.-3: Correlation of protease (neutrophil Elastase), antiprotease (alpha-1-antitrypsin) with pulmonary function parameters in healthy controls and different Stages of COPD.

\begin{tabular}{|c|c|c|c|c|c|c|c|c|c|c|}
\hline \multirow[t]{2}{*}{ Parameters } & \multicolumn{2}{|c|}{ Controls $(n=60)$} & \multicolumn{2}{|c|}{$\begin{array}{c}\text { Stage I } \\
(n=51)\end{array}$} & \multicolumn{2}{|c|}{ Stage II $(n=57)$} & \multicolumn{2}{|c|}{ Stage III $(n=59)$} & \multicolumn{2}{|c|}{$\begin{array}{c}\text { Stage IV } \\
(n=53)\end{array}$} \\
\hline & $\mathbf{r}$ & $P$ value & $\mathbf{r}$ & $\begin{array}{c}P \\
\text { value }\end{array}$ & $\mathbf{r}$ & $\begin{array}{c}P \\
\text { Value }\end{array}$ & $\mathbf{r}$ & $\begin{array}{c}\mathbf{P} \\
\text { Value }\end{array}$ & $\mathbf{r}$ & $\begin{array}{c}\mathbf{P} \\
\text { value }\end{array}$ \\
\hline $\begin{array}{c}\text { Neutrophil } \\
\text { Elastase- } \\
\text { FEV1 \% } \\
\text { predicted }\end{array}$ & +0.147 & 0.262 & -0.760 & $\begin{array}{c}0.000 \\
1\end{array}$ & -0.796 & $\begin{array}{c}0.000 \\
1\end{array}$ & -0.851 & 0.001 & -0.974 & $\begin{array}{c}0.000 \\
1\end{array}$ \\
\hline $\begin{array}{c}\text { Alpha-1- } \\
\text { antitrypsin- } \\
\text { FEV1\% } \\
\text { predicted }\end{array}$ & +0.179 & 0.171 & +0.743 & $\begin{array}{c}0.000 \\
1\end{array}$ & +0.789 & $\begin{array}{c}0.000 \\
1\end{array}$ & +0.795 & 0.001 & $\begin{array}{c}+0.95 \\
1\end{array}$ & $\begin{array}{c}0.000 \\
1\end{array}$ \\
\hline $\begin{array}{c}\text { Neutrophil } \\
\text { Elastase- } \\
\text { FVC \% } \\
\text { predicted }\end{array}$ & +0.083 & 0.528 & -0.082 & 0.567 & -0.392 & 0.002 & -0.462 & 0.000 & -0.583 & $\begin{array}{c}0.000 \\
1\end{array}$ \\
\hline $\begin{array}{c}\text { Alpha-1- } \\
\text { antitrypsin- } \\
\text { FVC \% } \\
\text { predicted }\end{array}$ & +0.011 & 0.933 & +0.037 & 0.796 & +0.044 & 0.745 & +0.287 & 0.02 & $\begin{array}{c}+0.49 \\
8\end{array}$ & $\begin{array}{c}0.000 \\
1\end{array}$ \\
\hline $\begin{array}{c}\text { Neutrophil } \\
\text { Elastase- } \\
\text { FEV1/FVC } \\
\text { \% ratio }\end{array}$ & +0.090 & 0.494 & -0.189 & 0.184 & -0.412 & 0.001 & -0.518 & 0.001 & -0.636 & $\begin{array}{c}0.000 \\
1\end{array}$ \\
\hline $\begin{array}{c}\text { lpha-1- } \\
\text { antitrypsin- } \\
\text { FEV1/FVC } \\
\text { \% ratio }\end{array}$ & +0.047 & 0.721 & +0.122 & 0.393 & +0.269 & 0.04 & +0.293 & 0.02 & $\begin{array}{c}+0.62 \\
0\end{array}$ & $\begin{array}{c}0.000 \\
1\end{array}$ \\
\hline NE - A1AT & -0.043 & 0.744 & -0.350 & 0.01 & -0.421 & 0.001 & -0.667 & 0.001 & -0.948 & $\begin{array}{c}0.000 \\
1\end{array}$ \\
\hline
\end{tabular}

NE/A1AT Ratio in Stage I COPD

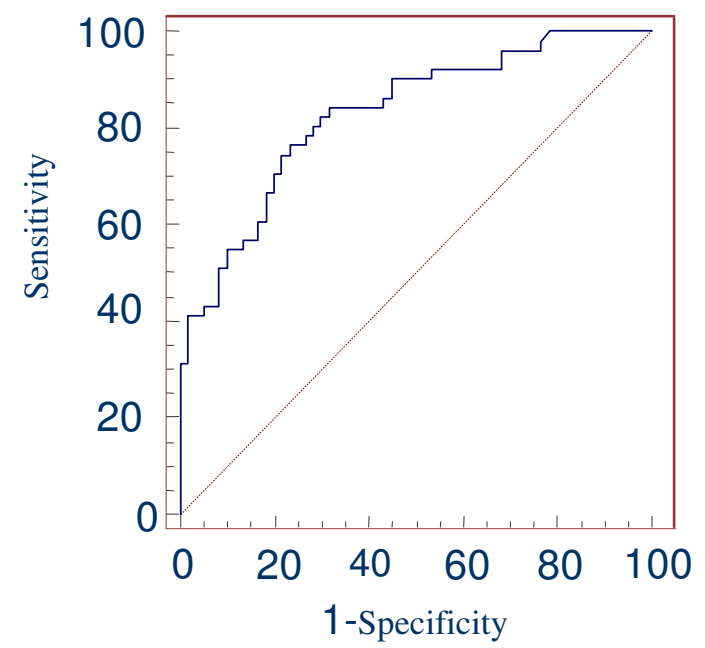

$\mathrm{AUC}=\mathbf{0 . 7 8 9}$,

Cut-off values of NE/A1AT for

Stage $\mathrm{I}=2.61 \times 10^{-7} \mathrm{mg} / \mathrm{dl}$

Fig.1. ROC curve analysis of NE/A1AT ratio in Stage I COPD patients 
NE/A1AT Ratio in Stage II COPD

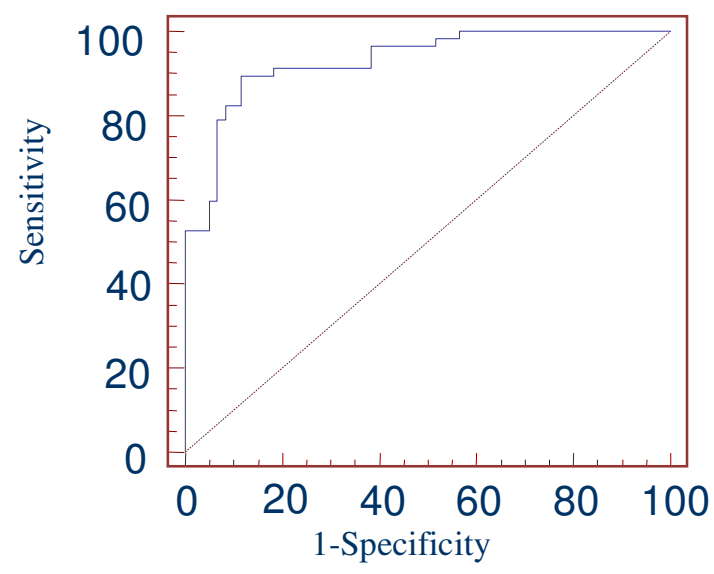

$\mathrm{AUC}=\mathbf{0 . 8 1 3}$,

Cut-off values of NE/A1AT for

Stage II $=3.13 \times 10^{-7} \mathrm{mg} / \mathrm{dl}$

Fig.2. ROC curve analysis of NE/A1AT ratio in Stage II COPD patients

NE/A1AT Ratio in Stage III COPD

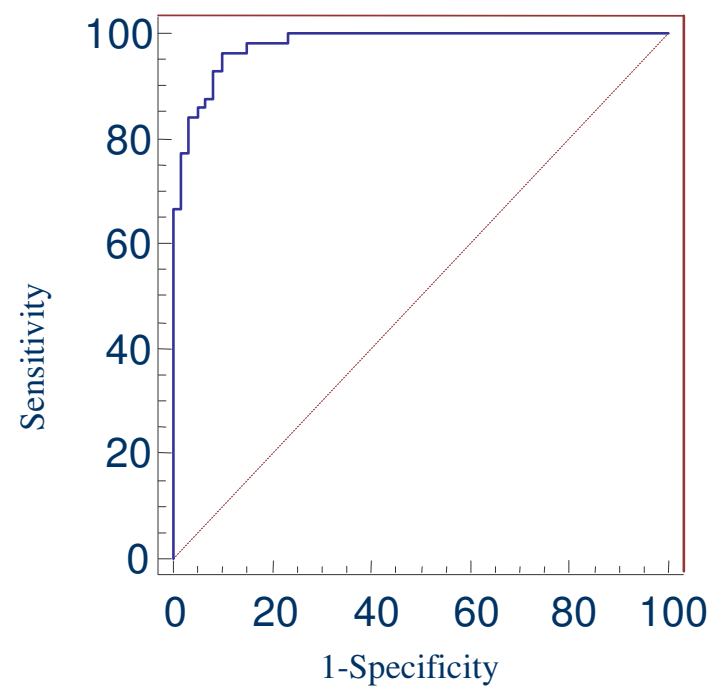

AUC $=0.971$,

Cut-off values of NE/A1AT for

Stage III $=4.35 \times 10^{-7} \mathrm{mg} / \mathrm{dl}$

Fig.3. ROC curve analysis of NE/A1AT ratio in Stage III COPD patients

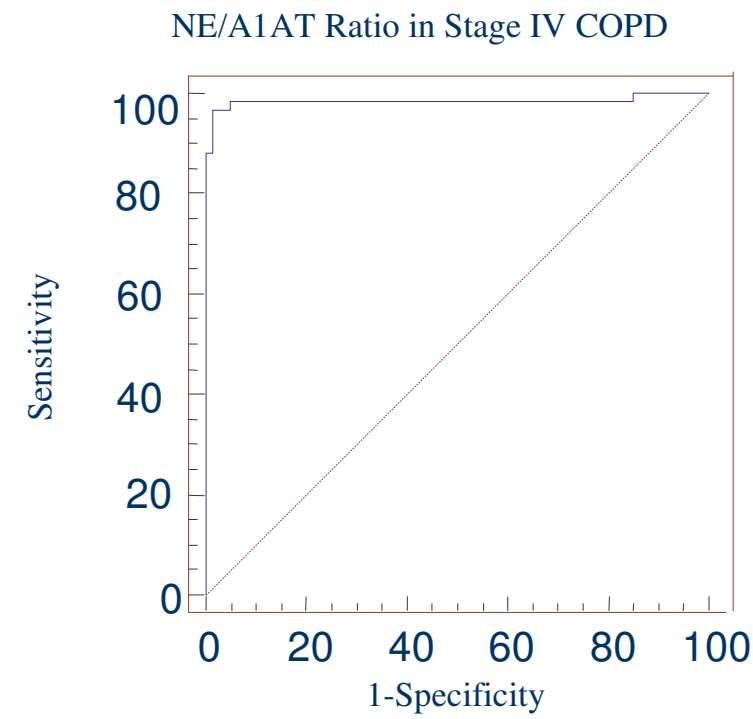

AUC=0.989,

Cut-off values of NE/A1AT for

Stage IV $=4.97 \times 10^{-7} \mathrm{mg} / \mathrm{dl}$

Fig.4. ROC curve analysis of NE/A1AT ratio in Stage IV COPD patients 
Table No.1 shows that irrespective of the sex in healthy volunteers the normal $\mathrm{FEV}_{1} \%$ predicted and $\mathrm{FEV}_{1} / \mathrm{FVC}$ $\%$ ratio was observed, which decreases with the advancement of the stage.

Table no. 2 shows mean \pm S.D values of alpha-1-antitrypsin, neutrophil elastase and neutrophil elastase/alpha-1antitrypsin ratio in healthy controls and different stages of COPD patients. In our study, we observed significantly decrease levels of alpha-1-antitrypsin (A1AT) from stage I to stage IV COPD patients as compared to the levels in healthy controls. When we did intergroup comparison of mean values of serum A1AT level of stage I vs. stage II, III and stage IV we found significantly decrease levels of A1AT in stage II, III and IV COPD (Table no.2).

As shown in table no. 3 we found significant positive correlation of A1AT with FEV1\% predicted in stage I, II, III and in stage IV COPD patients. In addition to this, we obtained positive correlation between A1AT with FVC\% only in stage III and stage IV COPD. We observed positive correlation between $\mathrm{FEV}_{1} / \mathrm{FVC} \%$ ratio with A1AT in stage II, III, IV COPD patients (table no.3). As shown in table no.3 we found strong negative correlation between serum neutrophil elastase with alpha-1-antitrypsin $(\mathrm{r}=-0.350, \mathrm{P}=0.01 ; \mathrm{r}=-0.421, \mathrm{P}=$ $0.0003 ; \mathrm{r}=-0.667, \mathrm{P}<0.001 ; \mathrm{r}=-0.948, \mathrm{P}=0.0001)$ respectively in stage I, II, III and IV of COPD.

Neutrophil elastase is a degrading enzyme. Mean \pm SD values of serum neutrophil elastase as shown in table no.2. In our study we observed increased levels of neutrophil elastase from stage I to stage IV of COPD as compared to the healthy controls. When intergroup comparison was done we found statistically significant increase activity of serum neutrophil elastase in all stages of COPD according to the severity of the disease (table no.2). As shown in table no. 3 we found significant negative correlation between neutrophil elastase with FEV1\% predicted in stage I, II, III and IV COPD. We obtained inverse correlation between FVC\% predicted and FEV1/FVC \% ratio with neutrophil elastase only in stage II, III and in stage IV COPD (table no.3). To test the ability of serum neutrophil elastase/alpha-1-antitrypsin ratio as biomarker the cut off value of neutrophil elastase/alpha-1-antitrypsin ratio was determined by ROC curve analysis. The cut-off point value of NE/A1AT ratio for stage $\mathrm{I} 2.61 \times 10^{-7} \mathrm{mg} / \mathrm{dl}(\mathrm{AUC}=0.789, \mathrm{SE}=0.03,95 \% \mathrm{CI}=0.69$ to $0.85, \mathrm{P}<0.0001), 3.13 \times 10^{-7} \mathrm{mg} / \mathrm{dl}$ for stage II $(\mathrm{AUC}=0.813, \mathrm{SE}=0.02,95 \% \mathrm{CI}=0.74$ to $0.87, \mathrm{P}<0.0001), 4.35 \mathrm{X}^{-7}{ }^{-7} \mathrm{mg} / \mathrm{dl}$ for stage III $(\mathrm{AUC}=$ $0.971, \mathrm{SE}=0.01,95 \% \mathrm{CI}=0.91$ to $0.99, \mathrm{P}<0.0001$ ), $4.97 \times 10^{-7} \mathrm{mg} / \mathrm{dl}$ for stage IV (AUC=0.989, SE=0.01, $95 \% \mathrm{CI}=0.94$ to $0.99, \mathrm{P}<0.0001)$. At this cut-off levels of Neutrophil elastase/alpha-1-antitrypsin ratio, we achieved a sensitivity of $74 \%(95 \% \mathrm{CI}=60.5$ to 85.2$)$ and specificity of $60.7 \%(95 \% \mathrm{CI}=46.5$ to 72.4$)$ respectively for stage $\mathrm{I}$, a sensitivity of $80.70 \%(95 \% \mathrm{CI}=68.0$ to 90.0$)$ and specificity of $88.3 \%(95 \% \mathrm{CI}=77.4$ to 95.2$)$ for stage II, a sensitivity of $98.30 \%(95 \% \mathrm{CI}=90.0$ to 100.0$)$ and specificity of $100 \%(95 \% \mathrm{CI}=94.0$ to $100.0)$ for stage III, a sensitivity of $100 \%(95 \% \mathrm{CI}=93.3$ to 100$)$ and specificity of $100 \%(95 \% \mathrm{CI}=94.0$ to 100.0) for stage IV (Fig. no. 1,2, 3 and 4)

\section{Discussion}

Free radicals present in the tobacco smoke that directly penetrate into the respiratory tract system, then reach the lung alveoli, generate reactive oxygen species and other oxidants/ free radicals which is the main factor for the development of COPD[20]. Free radical not only damage lipids, proteins, DNA but also modulates some processes such as increased production of mucus, impaired cilia function, loss of elasticity of the alveoli of lungs, increased airway obstruction that leads to the development of COPD [21]. In our study we found significantly decreased levels of $\mathrm{FEV}_{1} \%$ predicted, $\mathrm{FVC} \%$ predicted, $\mathrm{FEV}_{1} / \mathrm{FVC} \%$ ratio in all stages of COPD patients (table no.1). Daphne CR et al observed similar observation in their study [22].
This decline in lung function parameters might be due to the structural changes in the airways and alveoli of lungs of COPD patients which include inflammation in lung tissues, airway remodeling, mucus hypersecretion, bronchospasm, increased airway resistance and loss of elastic recoil resulting in progressive decreased expiratory airflow. This decreased airflow obstruction causes generation of reactive oxygen species and free radicals.

The lungs destroy most of the toxins, particles and infectious agents because of its large surface area before any organ does. Tobacco smoking, inhalation of air pollutant and bacterial infection result in lung irritation and migration of neutrophils 
and macrophages to these area of stress [23,24]. Neutrophil elastase is a powerful protease released from the neutrophils, it destroys the extracellular matrix, modifies airway epithelial cells and it disturbed respiratory host defense mechanisms [25]. An increased level of serum neutrophil elastase has been reported in disease of cystic fibrosis, acute respiratory distress syndrome (ARDS) and lung cancer patients [26-28]. Information regarding serum levels of neutrophil elastase in COPD remains scant. To the best of our knowledge, we are first to report serum levels of neutrophil elastase in different stages of COPD patients. In present study, we observed increased levels of neutrophil elastase from stage I to stage IV of COPD as compared to the levels in healthy controls.

When intergroup comparison was done we found statistically significant increase in serum neutrophil elastase in all stages of COPD according to the severity of the disease (Table no.2). Similar to our study, Borzi et al has reported elevated levels of serum neutrophil elastase in patients with idiopathic pulmonary fibrosis (IPF) [29]. The observed increased activity of neutrophil elastase in COPD patients could be due to overproduction of oxidants at the site of lung inflammation which oxidizes the methionine residue at the active site of alpha-1-antitrypsin therefore its inhibitory capacity on neutrophil elastase was lost, it cannot binds to the neutrophil elastase resulting more neutrophil elastase to release in the lungs and then into pulmonary circulation [30,31]. As a regards neutrophil elastase there were significant negative correlation between their levels with $\mathrm{FEV}_{1} \%$ predicted, $\mathrm{FEV}_{1} / \mathrm{FVC} \%$ ratio in stages of COPD patients.

Protease-Antiprotease balance is essential for the normal lung function. Normally, the lung is adequately protected against this neutrophil elastase by alpha-1-antitrypsin. A1AT is a protein that rapidly binds to these proteases, thereby it irreversibly inhibits their proteolytic activity. Alpha-1-antitrypsin is an important antiprotease. A1AT is synthesized in hepatocytes, neutrophils, macrophages, blood monocytes and in pulmonary alveolar cells. Various investigators have studied the protease- antiprotease imbalance in the development of respiratory conditions like bronchiectasis, bronchial asthma and in emphysema [32-34]. To the best of our knowledge, we are first to report serum levels of A1AT in different stages of COPD patients. In current study, we observed significantly decrease levels of A1AT from stage I to stage IV COPD patients as compared to the levels in healthy controls. When we did intergroup comparison of mean values of serum A1AT level of stage I vs. stage II, III and stage IV we found significantly decrease levels of A1AT in stage II, III and IV COPD (Table no. 2). These possible decrease levels of A1AT in COPD patients could be due to oxidants modified the structure of A1AT. This results in conformational change occurred in the structure of A1AT, resulting alpha-1-antitrypsin limits the passage of liver to blood circulation and then to the lungs [35].

Therefore the availability of A1AT in the lung and in blood circulation may be less in stages of COPD patients. Similar to our study, Gaillard et al has reported markedly reduced plasma elastase inhibitory capacity in asthmatic patients as compared to non-asthmatic patients [36]. In contrast to our study, Jadhav BS et al (2013) reported increased levels of alpha-1-antitrypsin in stages of COPD patients [5]. In our study we obtained positive correlation of A1AT with $\mathrm{FEV}_{1} \%$ predicted in stage I, II, III and in stage IV COPD patients. A1AT correlated positively with $\mathrm{FVC} \%$ only in stage III and in stage IV COPD. We observed direct correlation between $\mathrm{FEV}_{1} / \mathrm{FVC} \%$ ratio with A1AT in stage II, III, IV COPD patients (Table no.3). In contrast to our finding, Rai RR et al [6] have reported negative correlation between $\mathrm{A} 1 \mathrm{AT}$ and $\mathrm{FEV}_{1} \%$ predicted in COPD patients. In correlation study we found strong negative correlation between serum NE with alpha-1antitrypsin $(\mathrm{r}=-0.350, \mathrm{P}=0.01 ; \mathrm{r}=-0.421$, $\mathrm{P}=0.0003 ; \mathrm{r}=-0.667, \mathrm{P}<0.001 ; \mathrm{r}=-0.948, \mathrm{P}=$ 0.0001 , table no.3) respectively in stage I, II, III and IV of COPD.

The normal function of the lungs depends on the protease -antiprotease balance. In physiological conditions activity of neutrophil elastase is inhibited by $\alpha$-1-antitrypsin. In oxidative stress condition $\alpha$-1-antitrypsin becomes functionally inactive due to oxidation of methionine residue on active site of enzyme. Therefore inhibitory action of $\alpha$-1-antitrypsin on neutrophil elastase is lost resulting more NE released in the lungs. Neutrophil elastase enzymes break down elastin, collagen, 
proteoglycan and laminin components of extracellular matrix of lung tissues [25], therefore increased fibrosis of lung tissues and that leads to development of emphysema and COPD. In our study we observed increased levels of neutrophil elastase/ $\alpha$-1-antitrypsin ratio from stage I to IV of COPD as compared to healthy controls $(\mathrm{P}=0.001)$.

When intergroup comparison was done of serum neutrophil elastase/alpha-1-antitrypsin ratio of stage I vs. stage II, stage III and stage IV of COPD we found significant increased in protease/antiprotease ratio in stage II, III, IV COPD as compared to stage I $(\mathrm{P}=0.012, \mathrm{P}=0.001$, $\mathrm{P}=0.001$ ) respectively (Table no.2). From these findings, we suggest that this neutrophil elastase/ $\alpha$ 1 -antitrypsin ratio can tell us the severity of the chronic obstructive pulmonary disease in terms of increased fibrosis of the lung tissue.

To prove the efficacy of Neutrophil elastase /Alpha-1-antitrypsin ratio as a biomarker we did ROC curve analysis which revealed the cut-off values of neutrophil elastase/ alpha-1-antitrypsin ratio $2.61 \mathrm{X} 10^{-7} \mathrm{mg} / \mathrm{dl}$ for stage $\mathrm{I}(\mathrm{AUC}=0.789$, $\mathrm{SE}=0.03,95 \% \mathrm{CI}=0.69$ to $0.85, \mathrm{P}<0.0001), 3.13$ $\mathrm{X} 10^{-7} \mathrm{mg} / \mathrm{dl}$ for stage II $(\mathrm{AUC}=0.813, \mathrm{SE}=0.02$, $95 \% \mathrm{CI}=0.74$ to $0.87, \mathrm{P}<0.0001), 4.35 \times 10^{-7} \mathrm{mg} / \mathrm{dl}$ for stage III $(\mathrm{AUC}=0.971, \mathrm{SE}=0.01,95 \% \mathrm{CI}=0.91$ to $0.99, \mathrm{P}<0.0001), 4.97 \times 10^{-7} \mathrm{mg} / \mathrm{dl}$ for stage IV (AUC $=0.989, \mathrm{SE}=0.01,95 \% \mathrm{CI}=0.94$ to 0.99 , $\mathrm{P}<0.0001)$.

At this cut-off levels of Neutrophil elastase/alpha1 -antitrypsin ratio, we achieved a sensitivity of $74 \%(95 \% \mathrm{CI}=60.5$ to 85.2$)$ and specificity of 60.7 $\%(95 \% \mathrm{CI}=46.5$ to 72.4$)$ respectively for stage I, a sensitivity of $80.70 \%(95 \% \mathrm{CI}=68.0$ to 90.0$)$ and specificity of $88.3 \%(95 \% \mathrm{CI}=77.4$ to 95.2$)$ for stage II, a sensitivity of $98.30 \%(95 \% \mathrm{CI}=90.0$ to $100.0)$ and specificity of $100 \%(95 \% \mathrm{CI}=94.0$ to 100.0 ) for stage III, a sensitivity of $100 \%$ $(95 \% \mathrm{CI}=93.3$ to 100$)$ and specificity of $100 \%$ (95\% CI $=94.0$ to 100.0 ) for stage IV (Figure no $1,2,3$ and 4$)$ ).

From our findings we can say that determination of serum levels of Neutrophil elastase/ Alpha-1antitrypsin ratio can be used as good classifier for discriminating the degree of severity in COPD patients, when patients is not able to performed spirometry.

\section{Conclusion}

From this result we conclude that neutrophil elastase and alpha-1-antitrypsin these circulating markers are candidate predictors for rapid decline of lung function in COPD patients. Neutrophil elastase/ $\alpha$-1-antitrypsin ratio can tell us the severity of the chronic obstructive pulmonary disease in terms of increased fibrosis of the lung.

Though the magnitude of neutrophil elastase/alpha1-antitrypsin ratio is minute, still it can be a good marker of pulmonary function in COPD patients (proved by ROC curve analysis).

Ethical Approval: The study protocol was examined and authorized by the Medical Research and Ethics Committee of the B.J. Govt. Medical College and Sassoon General Hospital in accordance with the ethical standards laid down in 1964 Declaration of Helsinki on biomedical research on human subjects. We have obtained necessary Institutional ethical approval [Ref.No. BJMC/IEC/Pharmac/D1210133-35]

\section{Strength and Limitations of the Study}

Strength: We are the first here to report the correlation between serum level of Neutrophil elastase, alpha-1-antitrypsin with the markers of airflow obstruction $\left(\mathrm{FEV}_{1} \%\right.$ predicted) in COPD patients.

Limitations: The present study was carried out with a relatively small number of subjects. It would be better to perform this study with greater number of subject in order to determine the difference between the analysis of biochemical and lung function parameters of COPD patients and healthy control groups more clearly.

Acknowledgment: Author would like to thanks the patients who participated in this project as well as the personnel of Department of Pulmonary Medicine and Department of Biochemistry of B. J. Govt. Medical College and Sassoon General Hospital, Pune.

Funding: This research did not receive any specific grant from funding agencies in the public, commercial, or not-for-profit sectors.

Funding: Nil, Conflict of interest: None Permission of IRB: Not required 


\section{References}

1. Mathers CD, Loncar D. Projections of global mortality and burden of disease from 2002 to 2030 . PLoS Med. 2006 Nov;3(11):e442.

2. (GOLD) Global Strategy for the Diagnosis, Management, and Prevention of Chronic Obstructive Pulmonary Disease. 2013; February. Available at: http://www.goldcopd.org [PubMed]

3. Jindal SK, Aggarwal AN, Chaudhry K et al. A multicentric study on epidemiology of chronic obstructive pulmonary disease and its relationship with tobacco smoking and environmental tobacco smoke exposure. Indian J Chest Dis Allied Sci 2006; 48: 23-29.

4. Barnes PJ. Mediators of chronic obstructive pulmonary disease. Pharmacol Rev. 2004 Dec; 56 (4): $515-48$.

5. Jadhav BS, Bradapurkar JS, Bhagwat VR, Bardapukar SJ. Evaluation of total serum alpha-1antitrypsin and vitamin $\mathrm{E}$ in smoker and nonsmoker chronic obstructive pulmonary disease patients. Biomedicine 2013;33(4): 520-525

6. Rai R, Phadke M. Plasma antiprotease status in different respiratory disorders. The Internet Journal of Pulmonary Medicine.2006; 7(1):1-6

7. Carrell RW, Jeppsson JO, Laurell CB, Brennan SO, Owen MC, Vaughan L, Boswell DR. Structure and variation of human alpha 1-antitrypsin. Nature. 1982 Jul 22;298(5872):329-34.

8. Carrell RW, Jeppsson JO, Vaughan L, Brennan SO, Owen MC, Boswell DR. Human alpha 1antitrypsin: carbohydrate attachment and sequence homology. FEBS Lett. 1981 Dec 7;135(2):301-3.

9. Kalsheker N, Morley S, Morgan K. Gene regulation of the serine proteinase inhibitors alpha1-antitrypsin and alpha1-antichymotrypsin. Biochem Soc Trans 2002; 30(2):93-98.

10. Olsen GN, Harris JO, Castle JR, Waldman RH, Karmgard HJ: Alpha-1-antitrypsin content in the serum, alveolar macrophages, and alveolar lavage fluid of smoking and nonsmoking normal subjects. J Clin Invest 1975; 55(2):427-430.

11. Perlmutter DH, Cole FS, Kilbridge P, Rossing TH, Colten HR. Expression of the alpha 1proteinase inhibitor gene in human monocytes and macrophages. Proc Natl Acad Sci U S A. 1985 Feb; 82 (3):795-9.
12. Stockley RA. Proteases and antiproteases. Novartis Found Symp.2001;234:189-99; discussion 199-204.

13. Bühling F, Groneberg D, Welte T. Proteases and their role in chronic inflammatory lung diseases. Curr Drug Targets. 2006 Jun;7(6):751-9.

14. Lang MR, Fiaux GW, Gillooly M, Stewart JA, Hulmes DJ, Lamb D. Collagen content of alveolar wall tissue in emphysematous and non-emphysematous lungs. Thorax. 1994 Apr;49(4): 319-26.

15. Lee WL, Downey GP. Leukocyte elastase : Physiological function and role in acute lung injury. Am. J. Respir. Crit. Care Med.2001; 164(5): 896-904

16. Perlmutter DH, Pierce JA. The alpha 1antitrypsin gene and emphysema. Am J Physiol. 1989; 257(4 Pt 1): L147-62.

17. Carp H, Janoff A. Possible mechanism of emphysema in smokers in vitro suppression of serum elastase-inhibitory capacity by fresh cigarette smoke and its prevention by antioxidants. Am. Rev. Respir. Dis. 1978; 118(3): 617-621. doi: 10. 1164/ arrd.1978.118.3.617

18. Erickson JA, Jensen RA, Grenache DG. Enzyme linked immunosorbent assay for the determination of alpha-1-antitrypsin in serum and stool. Immuchrome Gmbh. The Journal of Applied Laboratory Medicine. 2016; 1(1):60-66. doi: 10. 1373/ jalm. 2016.020198 Published July 201

19. Enzyme linked immunosorbent assay for the determination of neutrophil elastase in serum. Wuhan EIAab Sci. Co. Ltd. Available at : http: //www.eiaab.com/entries/steps/ELISA\%20Kit/100 99_EIAAB/Human

20. Hatman TE, Tazeloar HD, Swensen SJ, Muller NL. Cigarette smoking: CT and pathological findings of associated pulmonary disease. Radiographics 1997;17(2): 377-390.

21. John ER, Aalt B, Ida L. Oxidative stress in chronic obstructive pulmonary disease. Oxidative stress study group. Am. J. Respir. Crit. Care. Med. 1997; 156(2 pt 1): 341-57. doi: 10.1164/ajrccm. 156.2.9611013

22. Daphne CR, James RJ, Nell H, Mae MS, Elvism I. Diagnostic value of post bronchodilator pulmonary function testing to distinguish between 
stable moderate to severe COPD and asthma. Intr.J. Chron. Obstruct.Pulmon Dis. 2008; 3(4): 693-699.

23. Hogg JC, Chu F, Utokaparch S, Woods R, Elliot WM, Buzatu L, Cherniack RM, Rogers RM, Sciurba FC, Coxson HO, Pare PD. The nature of small airway obstruction in COPD. N Eng J Med. 2004;350:2645-2653. doi:10.1056/NEJMoa032158

24. Saetta M, Turato G, Maestrelli P, Mapp CE, Fabrri LM. Cellular and structural bases of chronic obstructive pulmonary disease. Am. J. Respi. Crit. Care Med. 2001; 163(6):1304-9. doi: 10.1164/ ajrccm. 163.6.2009116

25. Fick RB, Naegel GP, Aquier S, Wood RE, Gee JBL, Reynold HY. Proteins of cystic fibrosis respiratory tract: fragmented immunoglobulin G opsonic antibody causing defective opsophagocytosis. J. Clin. Invest. 1984;74(1): 236-248. doi: 10.1172/JCI111407

26. Meyer KC, Lewandoski JR, Zimmerman JJ, Nunley D, Calhoun WJ, Dopico GA. Human neutrophil elastase and elastase/alpha1-antiprotease complex in cystic fibrosis : comparison with interstitial lung disease and evaluation of the effect of intravenously administered antibiotic therapy. Am Rev. Respir. Dis. 1991; 144 (3 pt 1):580-5. doi: https://doi.org/10.1164/ajrccm/144.3_Pt_1.580

27. Kodanma T, Yukioka H, Kato T, Kato N, Hato F, Kitagawa S. Neutrophil elastase as a predicting factor for development of acute lung injury. Internal Medicine. 2007; 46(11):699-94

28. Moroy G, Alix AJ, Sapi J, Hornebeck W, Bourguet E. Neutrophil elastase as a target in lung cancer. Anticancer Agents Med Chem. 2012 Jul;12 (6): 565-79.

29. Borzi RM, Grigolo B, Meliconi R, Fasano L, Sturani C, Fabbri M, Porstmann J, Fancchini A. Elevated serum superoxide dismutase levels correlate with disease severity and neutrophil degranulation in idiopathic pulmonary fibrosis.
Clin. Sci. (Lond) 1993;85(3):353-9. doi: 10.1042/cs 0850353

30. Beatty K, Bieth J, Travis J. Kinetics of association of serine proteinases with native and oxidized alpha-1-proteinase inhibitor and alpha-1antichymotrypsin. J Biol Chem. 1980 May 10;255 (9): 3931-4.

31. Taggart C, Cervantes-Laurean D, Kim G, McElvaney NG, Wehr N, Moss J, Levin RL. Oxidation of either methionine 351 or methionine 358 in $\alpha$-1-antitrypsin causes loss of antineutrophil elastase activity. J. Biol. Chem. 1980;275(35): 27258 -65. doi: 10.1074/jbc.M0048

32. Gadek JE, Pacht ER. The protease antiprotease balance within the human lung: implications for the pathogenesis of emphysema. Lung. 1990; 168 (1): 552-564. doi:10.1007/BF02718178

33. Kilore-Smith TA, Dowdeswell RJ, Gaillard MC. Elastase binding capacity of $\alpha 2$-macroglobulin in plasma of patients with asthma or chronic obstructive pulmonary disease without $\alpha-1$ protease inhibitor deficiency. Clinica Chimica Acta 1989;185(1):81-90.doi:10.1016/0009-8981(89) 90133-2

34.Denchev K, Radkov M, Lipcheva N. Changes in the level of alpha1-antitrypsin in bronchial asthma. Vutr Boles. 1977; 16(2):75-8.

35. Sohrab S, Petrusca DN, Lockett AD, Schweitzer KS, Rush NI, Gu Y, Kamocki K, Garrison J, Petrache I. Mechanism of alpha-1 antitrypsin endocytosis by lung endothelium. FASEB J. 2009 Sep;23(9):3149-58. doi: 10.1096/fj. 09- 129304. Epub 2009 May 7.

36. Gaillard MC, Kilore-Smith TA, Nogueira C, Dunn D, Jenkins T, Fine B, Kllenbach J. Alpha-1protease inhibitor in bronchial asthma: phenotypes and biochemical characteristics. Am Rev Respire Dis. 1992: 145(6) : 1311-5. doi: 10.1164/ ajrccm/ 145.6 .1311 .

\section{How to cite this article?}

Pawar R.S, Abhang S.A. Evaluation of neutrophil elastase/ alpha-1-antitrypsin ratio in different stages of chronic obstructive pulmonary disease (COPD) patients. Int J Med Res Rev 2017;5(07):664-674. doi:10.17511/ijmrr. 2017.i07.04. 